\title{
American University of Beirut
}

\author{
By Samuel Fustukjian
}

Director of the Library

American University of Beirut

\section{How an academic library functions in war-ravaged Lebanon.}

\author{
The land may vary more; \\ But wherever the truth may be \\ The water comes ashore, \\ And the people look at the sea.
}

-Robert Frost, Neither Out Far Nor In Deep

\begin{abstract}
A
merican University of Beirut Library with its four branches is one of the most distinguished in any Arab nation. It was founded in 1866, the same year as the university. It has passed through a series of developmental phases and today contains nearly 450,000 volumes, 1 million microform pieces, and 4,200 periodical titles distributed among the main, medical, science/agriculture, and engineering/architecture libraries.

In addition to its size, however, the library is acclaimed for the unique character and quality of its collections. The book collection has been developed to do more than just support the academic programs of the university. To enhance the university's unique role as a center for Middle Eastern studies, the library's collection reflects and chronicles the historical, political, and cultural interests of the community. English and Arabic are the primary languages of the collection. However, French, Armenian, Turkish, Russian, and German titles form a substantial part, reflecting the linguistic and historical diversity of the region.

American University of Beirut Library also presents a mosaic of exceptional special collections.
\end{abstract}

Its extensive collection of Arabic manuscripts is unrivaled. Its archival collection, chronicling the history of the University, contains numerous diaries of American missionaries who worked and traveled in Lebanon and other parts of the Middle East. The collection of photographs depicting scenes of Lebanon and the Middle East as seen through the eyes and lenses of such artists as Bonfils, Dumas, and Sarafian is unmatched in quality, uniqueness, and historicity.

My first reaction when entering AUB's walled campus was that of surprise-surprise at the shocking difference between the campus and the ravaged metropolis surrounding it. As the latter is noisy, destroyed, and filthy, so is the former quiet, clean, untouched, and beautiful. The 73-acre campus with its tile-roofed buildings, landscaped grounds, tennis courts, and magnificent beach is a vivid reminder of what Beirut used to be.

In spite of the shellings that the campus received during September 1983 and February 1984, AUB has survived the ten-year-old war mostly intact. Irrespective of its geographical location, AUB is considered by all factions as too valuable an asset to harm or destroy. All the political and religious parties of Lebanon have members who graduated from AUB. Consequently AUB commands considerable love and affection among the Lebanese population.

In view of this fact, AUB has stayed out of the massive Lebanese conflict. However, the reverse has not been true. To say that the effect of the conflict upon the campus, its staff, students, and li- 
brary has been profound would be an understatement. Efforts have been made to keep life in the city and work on campus separate. However, this valiant struggle to keep the war outside the university and the library walls frequently fails. The constant shelling is too close to ignore. The library staff may be stoic, but they are demoralized and deeply resent this constant intrusion into their efforts to lead normal lives.

The events that have taken place in the library during the past ten years, though not unique, are quite phenomenal. Whenever you have 80 people working together all day long in one location, tension is expected. At the library, however, where the daily and incessant turmoil of the outside infringes upon the workplace, the consequences of this tension intensify drastically. A sense of impending doom clashes and coexists with the determination to survive and grow. This amalgamation of conflicting desires manifests itself in increased professional self-expectations, intellectual complacency, and ideological prudence.

In its simplest form, this conflict is seen in the library's efforts to automate. Plans to establish a telecommunications link with the U.S. are thwarted by the fact that most phones don't work, and those that do are frequently tapped. Thus, to do nothing becomes the prudent thing.

Moslems, Christians, and Druze work together in the same building, using great caution to keep politics out of their conversation. They maintain a thin veneer of restraint among themselves, while outside members of their respective communities bomb and kill each other. This continuous awareness sometimes raises the tension inside the library almost to the breaking point. One wonders, however, if there will come a time when this veneer will shatter and the library will become an arena of hostility and violence, parallel to that going on in the city and the country.

Pocket-sized radios have become a standard piece of equipment within most library departments. Different broadcast stations alert listeners to which roads are safe to travel and which areas have been shelled. Those who belong to a group other than the majority in their department tend to have their own radio and listen to a station that they believe in. In Lebanon, any truths that are broadcast are partisan truths. It is a fatalistic pantomime: every hour on the hour, all heads lower, radios turn on, and faces assume expressions of grim expectation. When the newscast is over, library staff make a valiant effort to go on with their work and do their best. They do this day in and day out, hoping and waiting, alone in a crowd, and...listening to the radio.

In spite of the adverse effect that ten years of fighting have had on the university and its library, it is surprising how well their basic services have functioned. In a land where ten years of chaos have been the rule, the library has maintained a great degree of efficiency and dedication to its users.
September 1983 was the month during which we had planned to conduct an inventory. Normally, inventories are tedious and considered necessary evils at best. However, at AUB we used it as a means of maintaining a sense of normalcy, and that fact made it one of the most significant events of the year. We suspected that there were a great many losses due to the years of war, as well as

\section{The inventory started when the shelling was at its worst.}

greater losses left unaccounted for in other places. We knew that this activity was more than an effort to find out what was missing. It was an effort to bring life down to an organized, controllable, and measurable dimension.

The inventory started during the first part of September when the fighting was at its worst. Shells were falling at the rate of one every two seconds. On campus the biology building, the infirmary, and several dormitories were hit. A mortar scored an "ace" on our favorite tennis court. Soon 24-hour curfew was imposed upon the city. In spite of these tremendous odds, the library continued with its complete inventory. Furthermore, at any given time $60-95 \%$ of the staff was present and contributed to the project. Ultimately it proved to be a most efficient, thorough, and productive inventory.

Naturally the library and its staff bear scars of the violence of the past decade. Many of these have developed into permanent idiosyncracies. Others I hope are only temporary. The following are some of the idiosyncracies:

a. Staff. Many of the professional librarians have left Beirut. It has been difficult to replace them, and several of their positions were excised in order to ease the university's financial problems. This shortage of staff has hampered the library's efforts to forge ahead, automate, design new library instruction programs, preserve archives, and develop staff. Remarkably, those who were left behind have been able to carry on most of the library functions without interruption.

b. Book collection. During the prolonged conflict many students and faculty left the country without returning borrowed books. Some could not even come to the campus. Still others declared they had lost their houses, possessions, and library books during the Israeli invasion. These claims were difficult to disprove, and the losses were absorbed as unavoidable. On the other hand, many faculty brought back the numerous books they had taken from the library to safeguard against possible vandalism. 
c. Censorship. All books are shipped to Lebanon by air freight. Boxes are inspected at the airport to prevent books dealing with sensitive issues from coming into the country. Quite often "sensitive issues" would extend to such subjects as Etruscan vases, depending on the fancy of the airport censor. Frequently these officials are educationally handicapped and ill-prepared to pass competent judg-

\section{Any truths that are \\ broadcast are partisan}

truths.

ment on these issues.

d. Library hours. Due to curfew and difficulty in finding transportation over the green line, this year the library had to make adjustments in its hours and staffing. The library would be open only from 50 to 80 hours per week, depending upon political conditions.

e. Library privileges for non-university people. As the premier research collection in Lebanon, AUB libraries have always catered to many users outside the university. As security became tight, only people with AUB identification were allowed

\section{Lebanon update}

When the accompanying article about the American University of Beirut was written, the author, Samuel Fustukjian, had been director of AUB's Jafet Library since January 1983. Currently he is serving as director of the library at the University of South Florida, St. Petersburg campus. He was on vacation when the recent Beirut crisis occurred and the university was closed.

The night before he left Beirut, he and his wife Cynthia (also a professional librarian) celebrated her birthday with champagne and cake at the house of AUB president Malcolm Kerr. Kerr was tragically assassinated two weeks later.

At this time there is some doubt as to whether the recent cease-fire will allow the university and its library to re-open. Even if it does, many faculty, students and staff may be unwilling to return, creating severe manpower and revenue shortages.-GME. to come in. The library had to react and help its non-AUB patrons gain access to the premises. Deciding who could and could not be granted this clearance put constant pressure on the library administration.

f. Annual leave. Surprisingly this became a serious problem for an administrator to solve. Early on it became apparent that the only way one could enjoy a vacation was by leaving the country. Lebanon, a vacationers' paradise in the past, had virtually no place where one could enjoy peace and quiet away from shelling or enemy occupation.

Leaving the country, however, is not easy. The airport closes with consistent unpredictability. There is constant fear that you may leave but be unable to return, forcing you to take an extended vacation that you can ill afford. Many save their annual leaves to use when they cannot cross the green line to come to work. Library staff who attended the IFLA conference in August 1983 could not return to Lebanon in time because the airport had closed. Their forced vacation did not turn out to be pleasant, since they spent most of their time listening to the radio or reading newspapers to get news of Lebanon.

In spite of the intensity of the horror that has surrounded Lebanon, it is the duration that has demoralized and subdued most of its population. There seems no end in sight to the terror that has forced them into benumbed resignation. For how long can this winter of violence blanket the warravaged country? For how long can people's will to rebound endure?

\section{Beirut bombing study}

On October 23, 1983, a truck laden with the equivalent of over 12,000 pounds of TNT crashed the perimeter of the U.S. compound at Beirut International Airport, entered the Battalion Landing Team Headquarters, and resulted in the deaths of 241 U.S. military personnel. In less than two weeks a commission was convened by the Secretary of Defense to conduct an independent inquiry into the terrorist attack. The commission's report has now been released.

The Report on the DOD Commission on Beirut International Airport Terrorist Act, October 23, 1983, is a 150-page collection of information about the attack. It contains answers to questions on the Marines' performance, security, intelligence support, casualty handling, and accountability.

Copies, GPO stock number 008-000-004005 , may be ordered (prepaid only) for $\$ 4.75$ from Dept. 36-EP, Superintendent of Documents, Washington, DC 20402. 